\title{
What can we learn from Dordrecht for a possible authentic Confessio Africana?
}

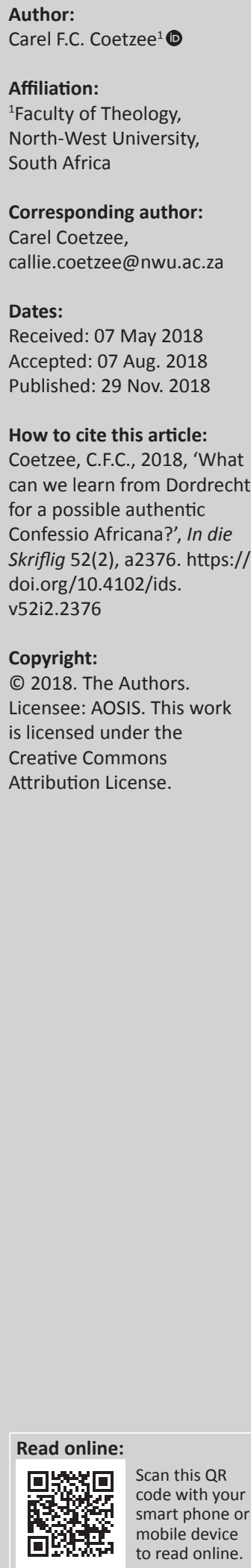

The year 2018 marks the 400th commemoration of the Synod of Dordt, the most important synod of reformed churches in the Post-Reformation era. The Synod was convened by the States General of the Netherlands after decades of serious conflict and unrest in the Dutch churches, over the Arminian heresy regarding the doctrine on predestination. The Synod also had an international character since it was also attended by theologians from churches all over Europe and England. The main purpose of the Synod was to seek a resolution of the Arminian controversy and formulate a judgement on the Remonstrance of 1610. After a wearisome process of evaluating the writings of the Remonstrants, and a thorough studying of Scripture, the Canons of Dordt was approved and signed by all the delegates. In the years to come it was recognised as a confessional standard together with the Belgic Confession and the Heidelberg Catechism. As far as a possible authentic Confessio Africana is concerned, efforts in the past to draft such a confession were not successful. We learn from Dordt (as well as the drafting of other reformed confessions through the ages) that a true reformed confession is born resulting from the judgement of the churches on a fundamental doctrinal issue. Such a confession must be recognised and accepted by churches internationally because it is in accordance with the Word of God.

\section{Introduction}

The year 2018 is a very important year for churches in the reformed tradition as well as for reformed theology. It is the 400th commemoration of the Synod of Dordt, held in the city of Dordrecht in the Netherlands from 13 November 1618 to 29 May 1619 (Noordzij 1997:80; Van 't Spijker 1987a:116; Verboom 2005:201). This synod is without any doubt the most important synod of reformed churches in the Post-Reformation era. Sinnema (2017) describes it as 'the most significant church assembly in the reformed tradition'. Not only did the synod draw up the Canons of Dordt against the Five Articles of the 1610 Remonstrance (Sinnema 2011:313), but also the well-known Church Order of Dordt (Van 't Spijker 1987a:116) as well as to give a clear mandate for a new Dutch translation of the holy Scripture, the so-called 'Statenvertalen' (cf. De Bruin 1987:138-141). ${ }^{1}$

At the commemoration of this historic event of 400 years ago, the very important question is whether the Synod of Dordt and the decisions taken there are still relevant today.

The question can undeniably be answered in the affirmative as far as the contents of the decisions of Dordt is concerned. The Church Order of Dordt is in its essence still maintained by many reformed churches in the world. And the Canons of Dordt is even more relevant than ever because the heresy ${ }^{2}$ of the Remonstrants (also called Arminianism) ${ }^{3}$ is more alive than ever ${ }^{4}$. The reformed faith and theology are threatened more and more by the five points of Arminianism, namely (1) election based on foreseen faith, (2) the universal merits of Christ, (3) the free will of man due to only partial depravity, (4) the resistibility of grace, and (5) the possibility of a lapse from grace (cf. e.g. Beeke 1999:96; Coetzee 2018a:6). Furthermore, it will be worthwhile to do research on the question whether there are any fundamental differences between Arminianism and Pentecostalism.

In this article, however, the question of the relevance of the Synod of Dordt for today is dealt with from a different, rather formal or technical angle, namely the question whether we can learn 1.in the context of this article,, focus primarily on the drafting of the Canons.

2.This article is written from a reformed perspective. In that sense, the viewpoint of the Remonstrants can be called a very serious heresy. 3.Derived from the name of Jacob Arminius (1560-1609), the Dutch theologian who first questioned the reformed doctrine of predestination (cf. Botha 2008:68).

4.A Google search on the key word Arminianism delivered 674000 results in $0.37 \mathrm{~s}$. The debate between Arminianism and Calvinism is an ongoing debate, four centuries after the Synod of Dordt. Cf. in this regard, Walls and Dongell (2004); 'Why I am not a Calvinist', and Peterson and Williams (2004): 'Why I am not an Arminian'. 
something from Dordt for a possible Confessio Africana. The article therefore focuses mainly on matters like the formulation of a confession, the characteristics of a reformed confession, the need for a new confession, specifically in the African context, against the background of the way in which the Synod of Dordt dealt with the matters on its agenda.

\section{Historical background: Relevant facts}

The Synod of Dordt was preceded by many years of 'serious controversy' (Beeke 1999:96) in the Dutch churches initiated by the rise of Arminianism (cf. Van 't Spijker 1987b:11-56 for an overview of the preceding history).

Jacob Arminius's controversial viewpoint on aspects of the doctrine on predestination can be traced back to the year 1590. He was then minister of the Reformed Church of Amsterdam and was asked by his church council to refute the viewpoint of Coornhert (Verboom 2005:21). Coornhert rejected certain articles of the Heidelberg Catechism as well as the doctrine on predestination of Calvin and Beza. Arminius realised that he agreed with Coornhert on certain points of his critique against Beza (Verboom 2005:21).

In the year 1603 Arminius was appointed as Professor at the University of Leiden (Botha 2008:68). On 7 February 1604 Arminius defended 15 theses on the doctrine of predestination in a disputation with his students (Verboom 2005:22). From this moment, the viewpoints of Arminius in which he questioned the reformed doctrine on predestination were officially known, not only in academic circles in Leiden, but also in the wider context of the church.

Arminius' opinion was that we are dependent upon God's grace, but this grace is given in such a way that we are left to decide, whether or not we will accept it (Lane 2007:184). 'God's grace makes our salvation possible, not inevitable' (Lane 2007). The ultimate choice regarding salvation is made by man. 'While for Augustine and Calvin it is ultimately true that we choose God because He has chosen us, for Arminius the reverse is true' (Lane 2007).

Arminius's viewpoints were opposed by one of his colleagues in Leiden: Prof. Gomarus. Gomarus also held a disputation on 31 October 1604 on the doctrine of predestination in which he defended the viewpoint of Beza (Verboom 2005:22-23).

Arminius was then called to account from the side of the church when the Classis of Dordrecht laid a charge at the Synod of South Holland (Verboom 2005:23).

In the light of the specific relationship between church and state at the time, the state also got involved. A conference was held in 1608 by the states of Holland and West-Friesland, and again in 1609 where Arminius and Gomarus could defend their respective viewpoints (Verboom 2005:23). Before the conference of 1609 could come to a final conclusion, Arminius became ill, and died on 19 October 1609 (Verboom 2005).
After the death of Arminius, the Arminian-Calvinist conflict continued. Forty-three followers of Arminius drafted and presented their heretical view to the States General of the Netherlands in the Remonstrance of 1610 (Beeke 1999:96). According to Beeke (1999) the conflict became so severe that it led the Netherlands to the brink of civil war. The Remonstrance can be divided into three sections. In the first section it deals with the background which led to the formulation of the Remonstrance. The second section contains the contents of the Remonstrance while the third section is a request for the support of the government (States General; cf. Verboom 2005:111-121).

Lane (2007) gives the following summary of the five points of the Remonstrance:

- God chose to save through Jesus Christ all those who through the grace of the Holy Spirit would believe in Him and persevere to the end.

- Jesus Christ, by his death on the cross, obtained forgiveness of sins for all, but only believers partake of it.

- Fallen man will of his own free will think nothing that is truly good.

- We can do no good without God's grace preceding, awakening, following and cooperating with us. But this grace is not irresistible.

- True believers are enabled by grace to persevere to the end and be saved. Arminians have usually tended to assert that it is possible to fall from grace and lose one's salvation. (p. 184)

The Contra-Remonstrants formulated a Contra-Remonstrance in which they defended the reformed doctrine against the heresy of the Arminians (cf. Van 't Spijker 1987b:38-46). ${ }^{5}$

According to Verboom (2005:122), the formulation of the Remonstrance was a deciding moment in the history of the Arminian controversy. It led to an irreparable schism in the churches.

From the side of the churches, they wanted the conflict to be dealt with and solved in an ecclesiastical manner (Van ' $t$ Spijker 1987b:38). An official synod could, however, only be convened by the States General.

It was only due to the influence of Prince Mauritz and Willem Lodewijk, that the matter of a National Synod was put on the agenda of the States General. After all the years of the conflict, it was decided that the Synod would convene in the city of Dordrecht (Van 't Spijker 1987b:56).

The first session of the Synod took place on Tuesday, 13 November 1618 in the Kloveniersdoelen in the city of Dordrecht (Verboom 2005:201). The opening was conducted on behalf of the States General by Martinus Gregorius. Church services were also held. About 100 delegates attended the synod, among whom were 37 ministers, 19 elders, five 5. In the context of this article, we cannot deal with the contents of the Remonstrance as well as the Contra-Remonstrance in depth. 
professors and 18 political commissioners. From abroad 23 theologians were present from England, the Paltz, Hessen Geneve, Bremen, Emden, Nassau and Wetteravia. In the second session, the moderamen was elected. Reverend Johannes Bogerman from Leeuwarden was elected as president, Jacob Rolandus and Hermanus Faukelius as assessors and Festus Hommius and Sebastianus Damman as secretaries (Verboom 2005).

The general purpose of the synod was to determine the authority of the confession, the formulation of the doctrinal differences and the formulation of a judgement on the Remonstrants (Verboom 2005:201). According to Sinnema (2011):

The Synod of Dort was originally convened by the Dutch government for one main purpose: to seek a resolution of the Arminian controversy that had caused major unrest in the Dutch churches for about two decades. (pp. 313-314)

Sinnema (2011) then quotes the ninth article of a decision taken by the States General on 11 November 1617, in which the Synod's basic agenda is spelled out:

\begin{abstract}
In the assembly the well-known Five Articles in controversy and the difficulties that have arisen from them, shall first and foremost be treated, in order to earnestly see how these may be removed from the churches with the least trouble and in the most proper manner, so that the peace of the church (but especially the purity of doctrine) may be preserved. Afterward, the remaining difficulties and gravamina - whether general or particular - relating to the churches, may be presented. (p. 314)
\end{abstract}

Van 't Spijker (1987b:26) also points out that the heart, the very core of the conflict in the Dutch churches, was nothing less than the heart of the gospel: the preaching of the grace of God to fallen, totally depraved people and the issue that came to the fore throughout the history of the church at the crossroads. In this regard the Contra-Remonstrants were convinced of the close connection between a pure corpus doctrinae as formulated in the reformed confessions and a reformed corpus disciplinae as formulated in a church order (Van 't Spijker 1987b:26). It is the task of a reformed church order, therefore, to guarantee the pure doctrine.

The Remonstrants (Arminians) on the other hand, had serious objections to certain articles of the confessions (the Heidelberg Catechism and the Belgic Confession) and they insisted on a revision of the confessions. In the years preceding the Synod of Dordt, as early as 1607, they expressed the viewpoint that a synod should revise the confessions, and that during such a synod, delegates should be exempted from their binding to the confession (Van 't Spijker 1987b:20).

The Synod of Dordt did not take the revision of the confessions to table. On the contrary, the synod focused on the judgement of the Five Articles in the Remonstrance of the Arminians.

At this point, an interesting historical development, initiated by the French reformed churches, should be briefly mentioned. More than 15 years before the Synod of Dordt, there was a movement within the French churches to bring reformed churches from all over Europe together to find a mutual doctrinal agreement, and so that the reformed churches of Europe could be more strongly united (Maag 2018). The aim was to take the confessions of all the reformed churches into account and draw up a mutually acceptable document. To reach this aim, any 'contentious topics liable to cause divisions, such as debates over free will, the perseverance of the saints, and predestination' should be avoided in such a document (Maag 2018). A document, known as the Tonneins document, was indeed drawn up.

However, before an international reformed conference, as envisioned by the French churches could take place, the Dutch government took the lead in calling together the Synod of Dordt to address the conflict with the Arminians (Maag 2018). The French Huguenot churches were also invited.

Due to political rather than religious factors, however, the king of France, Louis XIII, prohibited the four French delegates to attend the Synod of Dordt (Maag 2018). Yet although they were unable to attend the synod in person, they tried to influence the synod to accept their ideal of religious reconciliation among reformed churches:

In December 1618, Pierre Du Moulin wrote from Paris to the British ambassador in the Netherlands, Dudley Carleton, to urge him to get the synod delegates at Dordt to move beyond their focus on the Remonstrant threat and make progress on finding common doctrinal ground. (Maag 2018; cf. also Sinnema 2011:320)

Carleton transmitted Du Moulin's letter to King James, and president Bogerman even asked Bishop Carleton and Palatine theologian Scultetus to prepare a draft of such a confession (Sinnema 2011:320). Yet according to Maag (2018), among the Dutch leadership the feeling 'was distinctly lukewarm about the French suggestion, and any plans to start by drafting a mutually-acceptable confession for the reformed churches, were quietly dropped by early $1619^{\prime}$. According to Sinnema (2011:320), it was inter alia due to time constraints, that Bogerman no longer thought the project of a common confession 'was feasible for the Synod'. The matter was never officially discussed by the synod.

It is very interesting to note that by 1620 , at the National Synod of Alais, the Canons of Dordt were unanimously approved by the French churches, as 'conforming very much to the Word of God and to the Confession of Faith of our churches' (Sinnema 2011). This was probably because the Huguenots were worried about the potential penetration of Arminianism in France.

Back to Dordt: In the context of this article it is important to mention some facts about the procedure which the synod followed in doing its work. It is well known that very soon after the synod convened (on 16 November 1618; cf. Sinnema 2011:314) a letter was sent to 13 leading Remonstrants 'citing them to appear before the Synod to have their views examined and judged' (Sinnema 2011). It was expected from 
them to state, explain and defend their Five Articles and present any observations they had on the Belgic Confession and Heidelberg Catechism.

The Remonstrants were present in the synod for 6 weeks. Yet, since they did not fully cooperate, the proceedings were dominated by procedural matters (Sinnema 2011:314). It is significant that on 01 January 1619 the States General (not the delegates from the churches - CFCC) issued a resolution 'that declared that if the Remonstrants would not cooperate, their opinions should be investigated and determined from their writings' (Sinnema 2011).

The Remonstrants still did not cooperate and on 14 January the synod decided to implement the resolution of the States General, and the Remonstrants were expelled from the Synod.

From then on, the synod focused on examining and judging the Remonstrant views from their writings (Sinnema 2011:318). President Bogerman in this regard, orally advised the different delegations that in forming their judgements, not only the false doctrine of the Remonstrants should be rejected, but also the orthodox doctrine of the reformed churches should be set forth (Sinnema 2011).

From 6-21 of March 1619 the synod was occupied with reading the judgements (judicia) of the 19 delegations on the Five Articles of the Remonstrants. These judicia consisted of positive statements on the one hand, expressing the orthodox reformed view, as well as a rejection of the Remonstrant errors on the other hand, following the earlier instructions of Bogerman (Sinnema 2011:320). 'By this time, it was common to refer to the expected synodical judgement on the Five Articles as the "Canons"' (Sinnema 2011). ${ }^{6}$

On 22 March Bogerman presented his views on the form of the proposed Canons. He then continued to dictate to the Synod the Canons that he had drafted on Articles One and Two (Sinnema 2011):

This procedure immediately aroused the complaint of some foreign theologians that Bogerman intended to draw up the Canons by himself and merely dictate them to the Synod for its consent. (p. 321)

In the light of this discontent the civil delegates advised that some foreign and Dutch theologians work with the president and the assessors to draft the Canons (Sinnema 2011:321322). The Synod approved this advice and appointed a drafting committee of nine (Sinnema 2011:322). The drafting

6.The word Canons must not be understood in the same sense as the "Canon" of Scripture. Cf Sinnema (2011): The term Canons was used in various ways at the Synod of Dordt. While the term could sometimes be referring to synodical decisions in general and to articles of church order, even during the Synod, 'Canons became the general and to articles of church order, even during the Synod, "Canons became the popular term to describe the synodical judgement, though not its official name. Different delegates variously used the term Canons to refer to the positive articles, the rejected errors and most commonly to the whole document. But the draftin committee more precisely reserved the term Canons for the negative statements in the rejection of the errors section. This reflected the customary usage of other councils, for example the Council of Trent, which called anathematised statements: Canons. This should be taken as the primary meaning of the term Canons, even whe the term was extended to refer popularly to the whole document (pp. 331, 332). committee worked for about 3 weeks, while the Synod did not meet officially during this period (Sinnema 2011).

The drafting committee worked from Bogerman's draft but prepared its own draft of the Canons and revised it twice. The various delegations, then had the opportunity to suggest amendments after receiving the Bogerman draft and each of the three committee drafts (Sinnema 2011:322).

The above-mentioned facts regarding the procedure of the synod, are considered very important in the context of this article, namely to determine what can be learned from the Synod of Dordt for a possible Confessio Africana. The facts mentioned clearly illustrate how thoroughly the synod did its work in judging and examining such a very serious doctrinal issue.

Then in plenary sessions on 16, 18 and 23 April, the Synod, after some final changes, approved the final version of the Canons. Three copies were signed by all the delegates (Sinnema 2011:322). The whole document is titled: 'The judgement (judicium) of the Synod of Dordt on the five main points of doctrine in dispute in the Netherlands' (Sinnema 2011:322, 323).

A few days later a preface was added to the Canons, containing some pertinent comments reflecting how the Synod at this point perceived the nature and purpose of the Canons (Sinnema 2011:323).

This brings us to another very important point, namely the question of the confessional status of the Canons. Sinnema (2011:313-333) argues convincingly that the Synod of Dordt never had the intention to draw up a new confession, but only intended the Canons to be or to present its judgement or judicial decision on the Five Articles of the Remonstrance of 1610, drafted by the Arminians (313).

It is significant that in the advice of five delegations on the procedure of the Synod, in dealing with the ideas of the Remonstrants, the word 'confession' was never used. Instead, terms like 'Synodical judgement', 'Canons', 'decisive view' or 'final judgement' were used (317).

According to Sinnema (2011) the requirement that the Canons be subscribed does indeed mark a major step toward giving the Canons a confessional status:

Yet, even now it does not appear that the Synod was thinking of the Canons as a new confessional standard or document with confessional status. Rather, subscription was required since it was the most effective means of enforcing the doctrinal judgment made in the Canons and of preventing Remonstrant error in the Dutch Reformed churches. (p. 325)

On 15 May 1619, the Synod took a decision to draft a new form of subscription that required from ministers to subscribe not only to the Belgic Confession and the Heidelberg Catechism, but also to the Canons (Sinnema 2011:326). But even in this decision, the Canons are referred to as the 
'Synodical explanation concerning the Five Articles of the Remonstrants' (Sinnema 2011).

Sinnema (2011:327) then finally comes to the following conclusion:

Even though the Synod of Dordt did not make a specific decision to adopt the Canons as a new confession, including it in the form of subscription to be subscribed along with the Belgic Confession and Heidelberg Catechism de facto, it did give the Canons a confessional status parallel to these two official forms of unity. Requiring subscription meant that the Canons would function in the Dutch Reformed churches as a confessional standard by which to judge the orthodoxy of its leaders. (pp. 331-333)

In actual practice, however, it took some time before the Canons were fully recognised as having confessional status on a level with the Belgic Confession and Heidelberg Catechism. Even in the Church Order of Dordt, for example, the Canons were not accorded the same status (Sinnema 2011:327). But after some time, they came to be fully recognised as having confessional status. This occurred when the Canons began to be called a 'form of unity' along with the Belgic Confession and Heidelberg Catechism. Already at that time this was a technical term for documents with confessional status (Sinnema 2011:328). ${ }^{7}$

\section{Characteristics of and requirements for a reformed confession}

At this point, one needs to consider what the characteristics of and requirements for a reformed confession entail.

Pelikan (2003:2) distinguishes between a creed and a confession and quotes from Merriam-Webster's Collegiate Dictionary on the definition of a creed as 'a brief authoritative formula of religious belief' and a confession as 'a formal statement of religious beliefs'. These definitions make it clear that the words creed and confession can be used as synonyms.

Pelikan (2003) also points out that from the beginning in the history of the church there have been three presuppositions underlying the creedal and conciliar definition of orthodoxy:

first, that there is a straight line ... from the gospels to the creed; consequently, second, that the true doctrine being confessed by the councils and creeds of the church is identical with what the New Testament calls 'the faith which was once for all delivered to the saints' (Jude 3); and therefore, third, that continuity with that faith is the essence of orthodoxy, and discontinuity with it, the essence of heresy. (p. 9)

In texts like Romans 10:9 and Philippians 2:10-11 one already finds 'creedlike elements' in the New Testament (Pelikan

7.In the case of the Belgic Confession and the Heidelberg Catechism, it took some time before they were recognised as having confessional status. Although the Belgic Confession was originally drafted by one person (Guido de Brès), it was not Confession was originally drafted by one person (Guido de Bres), it was not recognised as confession before the churches gathered together in synods, and officially took such a decision. In the reformed churches in the so-called Low Countries, signing of the Belgic Confession was required as early as 1563. Only by 1593 the Heidelberg Catechism was beginning to be signed as a confessiona standard alongside the Belgic Confession. And only a few years after the beginning of the seventeenth century, both the Belgic Confession and the Heidelberg Catechism were referred to as 'forms of unity' (cf. Sinnema 2011:328).
2003:59, 60). Through the development in the early times of the New Testament church, the confessing of the faith that we find in the Bible became a confession, 'a formal, official, public, and binding statement of what is believed and confessed by the church' (Pelikan 2003:60). Every reformed confession should comply with these characteristics. Therefore, the creedal statements of later councils in the Early Church quote and incorporate the creeds of earlier councils (Pelikan 2003:60).

In this regard Pelikan (2003:61) refers to the conclusion of the Canons of Dordt, in which it is stated that the Canons set forth 'the clear, simple, and straightforward explanation of the orthodox teaching ... derived from God's word and in agreement with the confessions of the Reformed churches'. The conclusion of the Canons also calls upon other Christians of other confessions to look at the reformed confessions of the 16th century as well as at the synod's own formularies, and thus:

to form their judgment about the faith of the Reformed churches .... on the basis of the churches' own official confessions and of the present explanation of the orthodox teaching which has been endorsed by the unanimous consent of the members of the whole synod, one and all. (cf. also Beeke 1999:116, 117)

Pelikan (2003:64-92) continues to deal in depth with the confession as doctrine. Confessing the faith can never be less than doctrine, although it must always also be more than doctrine in the sense that it implies Christian obedience and a life of prayer and conformity to the divine will (Pelikan 2003:65).

One of the most persistent features of creeds and confessions, is therefore 'the utter seriousness with which they treat the issues of Christian doctrine as a matter of life and death both here in time and hereafter in eternity' (Pelikan 2003:70). Pelikan (2003:71) continues to quote Gregory of Nazianzus who says: 'Nothing is so magnificent in God's sight as pure doctrine, and a soul perfect in all the dogmas of the truth'.

In the last instance it can be said that a reformed confession should be ecumenical and accepted by churches in the reformed tradition internationally (cf. also Du Plooy 2012:68; Pelikan 2003:9).

As an authoritative, official and binding statement of what is believed and confessed by the church, such a confession must be subscribed to by church officials and church members. In the case of church officials, it must also be formally signed (cf. Janse van Rensburg 2012:63).

\section{The possibility of a Confessio Africana}

The possibility of a so-called Confessio Africana has been discussed by various scholars. Van Wyk (1993:285) expresses the need for a rather comprehensive Confessio Africana, but as motivation he only mentions a possible new ideology such as Apartheid. Van Wyk (1995:253-254) discusses the possibility of the extension of existing reformed confessions regarding doctrines, like the doctrine on Scripture, the church 
and the state and then states that a Confessio Africana could fulfill an important function in this regard.

Van Wyk (1995:254) also refers to some declarations, messages, and witnesses that were documented in South Africa at the end of the 20th century, like the Kairos document (1986/6), The Road to Damascus (1989), Kerk en Samelewing (Church and Society; 1986; 1990) and the Belhar Confession (1986).

As far as the Belhar Confession is concerned, the Uniting Reformed Church (Verenigende Gereformeerde Kerk) came to the drafting of it regarding their decision that a status confessionis was reached in South Africa because of the policy and system of Apartheid. They expected from the Dutch Reformed Church (Nederduitse Gereformeerde Kerk) to accept the Belhar Confession in the same sense or on the same level as the Three Forms of Unity (The Belgic Confession, the Heidelberg Catechism and the Canons of Dordt) as a condition to come to church unity. Jonker (1993:444) opines that Belhar has the status of an official confession. A number of studies, however, argued convincingly that the Belhar Confession cannot be compared to the Three Forms of Unity as far as doctrinal quality, focus, et cetera are concerned, and that it is not in accordance with the ecumenicity of the church for one denomination to draw up a 'confession' on its own, without allowing any inputs from other churches (cf. in this regard Du Plooy 2010:17-18; 2012:72; Janse van Rensburg 2012:60-65; Strauss 2012:73-78).

The possibility of a Confessio Africana was also discussed on several occasions by the 'Tussenkerklike Raad' (TKR; Interdenominational Council) of the Dutch Reformed Church (Nederduitse Gereformeerde Kerk), The Nederduitsch Hervormde Kerk van Afrika and the Reformed churches (Gereformeerde Kerke in Suid-Afrika). At a meeting in 2005 (Acta 30-31 August) it was decided to start thinking about a Confessio Africana. It should be done as widely as possible within the family of reformed churches. In 2006 (Acta 25-26 April) it was decided to start with a process to draw up a Confessio Africana. The interim committee was mandated to report back, while concerning the following aspects:

- The Belhar Confession must also be reckoned.

- Churches taking part in the Conventus of churches must also be involved.

- Other churches in the reformed tradition, especially in Africa, should also be involved.

On 13 October 2006 the interim committee asked the author of this article to draw up a memorandum in which attention should be given to the following aspects: The meaningfulness of the drafting of a Confessio Africana as well as matters preceding the formulation of a confession. This memorandum was tabled at a meeting in April 2007 (Acta 10-11 April). In the memorandum, the following concluding remarks were stated:

- The necessity for a new confession must be very clear in the light of a specific conflict about which no confession has yet been formulated, or the need to draw up such a confession on a specific aspect of the biblical doctrine, on which no confession has yet been formulated.
- A new confession should be relevant and binding in an ecumenical sense for churches in the same tradition.

- A new confession should be authoritative because it is in accordance with Scripture.

- A new confession must be clearly distinguishable from a re-formulation of an existing confession.

- A new confession must be clearly distinguished from a declaration of faith, witness, et cetera (Coetzee 2007:2).

After discussing this memorandum, the TKR decided not to continue with the possible drafting of a Confessio Africana. It was also decided to continue with the discussion with the emphasis on a declaration of faith rather than a confession (Acta 10-11 April 2007).

\section{Conclusion What can we learn from Dordrecht?}

In conclusion, in my view, the following lessons can be learned from Dordrecht as far as the drafting of a new confession (in this case a Confessio Africana) is concerned.

In the first place, a new confession is born because of churches dealing with unrest regarding an important or fundamental doctrinal issue. In the 17th century the Arminian-Calvinist conflict was 'so severe that it led the Netherlands to the brink of a civil war' (Beeke 1999:96; Sinnema 2011:313). Today, Arminianism still poses a serious threat to reformed churches and the reformed tradition. There is also the growing influence of the American ideas of Pentecostalism (cf. Coetzee 2017). However, in many cases, these ideas are tolerated. In cases where it is dealt with by way of church discipline, it is done with an appeal to the existing confessions. ${ }^{8}$

Furthermore, in the 17th century the reformed churches were very serious to maintain the sound doctrine in obedience to Scripture (cf. e.g. 1 Tm 6:3; Tt 2:1). In our times, however, we experience more and more what Paul says to Timothy: 'For the time will come when men will not put up with sound doctrine' (2 Tm 4:3). It must also be noted that the postmodern era in which we live, is not conducive to the drafting of a new confession. On the contrary, there is a growing negligence or apathy regarding doctrine.

Another important lesson is that as many churches as possible in the reformed tradition should be involved in the reflection on important or fundamental doctrinal issues. The Synod of Dordt had an international character since it was not only attended by delegates from the Dutch churches but also by 27 foreign delegates representing eight countries (Beeke 1999:96).

We can also learn from Dordrecht that it is a very wearisome and exhausting process to draft a possible new confession.

8.Existing reformed confessions deal extensively with the following doctrines, in judgement of the doctrines of Arminianism, Pentecostalism and other religious groups: The doctrine on Scripture (e.g. Belgic Confession Art. 2-7); the doctrine on Predestination (e.g. Belgic Confession, Art. 16 and the Canons of Dordt); the Perso and work of he Holy Spirit (e.g. Heidelberg Catechism, Lord's Day 20, Belgic Confession, Art. 22, 24); Infant Baptism (e.g. Heidelberg Catechism, Lord's Day 27, Belgic Confession, Art. 34); Ordo Salutis (e.g. Canons of Dordt, Chapter 3-4, 11, 12), et cetera. 
The Synod of Dordt held 154 formal sessions over a period of 7 months (Beeke 1999:96; Coetzee 2018b:1, 2). The Canons of Dordt were only formulated after a thoroughgoing study, mainly of Scripture.

Then, too, we must learn that the primary purpose should not be to draft a new confession, but to seek a resolution of or formulate a judgement on a certain doctrinal controversy (Sinnema 2011:313). The scriptural-based contents, doctrinal quality, subscription by churches worldwide in the reformed tradition, will eventually determine the confessional status or not, of such a judgement, as it happened in the case of each of the Three Forms of Unity.

What then is the responsibility of reformed churches, also in Africa, in the troubled times in which we live?

In the first place we should rediscover the treasure and richness of our reformed doctrine as formulated in our existing reformed confessions. Our confessions are living and alive and always relevant because they are in accordance with the Word of God (homologia).

We also have the responsibility, as reformed churches in Africa, to find a way to reflect together on relevant fundamental doctrinal issues, One example is the ongoing veneration of ancestral spirits, also among reformed believers. Such a reflection must be very thorough, and exegetically and doctrinally founded.

Such a reflection on one or more doctrinal issues can lead to the drafting of a declaration of faith or even a new confession that is acknowledged and accepted by churches, not only in Africa but also internationally.

In this regard the Faculty of Theology of the North-West University, together with the Theological School of the Reformed Churches in South Africa, in Potchefstroom (as a continuation of Refo 500), together with the churches, can perhaps take the initiative to bring churches and theologians together in a process of reflection.

\section{Acknowledgements Competing interests}

The author declares that he has no financial or personal relationships that may have inappropriately influenced him in writing this article.

\section{References}

Acta, see Tussenkerklike Raad

Beeke, J.R. (ed.), 1999, Doctrinal standards, liturgy, and the Church order, Reformation Heritage Books, Grand Rapids, MI.

Botha, S.J., 2008, 'Arminus, Jakob (1560-1609)', in F. Gaum, A. Boesak \& W. Botha (eds.), Christelike kernensiklopedie, p. 68, Lux Verbi.BM, Wellington.

Coetzee, C.F.C., 2007, 'Vertrekpunte vir'n nuwe belydenis', Memorandum, TKR, 10-11 April 2007, Unpublished.

Coetzee, C.F.C., 2017, 'Calvinism and Anabaptism: Is the debate still relevant?', in N. Vorster \& S.P. van der Walt (eds.), Reformed theology today: Biblical and systematic-theological perspectives, pp. 53-70, AOSIS, Cape Town.

Coetzee, C.F.C., 2018a, 'Wat is Arminianisme?', Die Kerkblad 119(3320), 6-7.

Coetzee, C.F.C., 2018b, 'Die ontstaan van 'n belydenis', Die Kerkblad 120(3323), 1-2.

De Bruin, C.C., 1987, 'De Bijbelvertaling', in W. van 't Spijker, C. de Bruin, H. Florijn, A. Moerkerken \& H. Natzijl (eds.), De Synode van Dordrecht in 1618 en 1619, pp. 121-156, Den Hertog, Houten.

Du Plooy, A. le R., 2010, 'Die Belydenis van Belhar en die ekumene teen die agtergrond van die Drie Formuliere van Eenheid', In die Skriflig 44(2), 1-20.

Du Plooy, D., 2012, 'Gemeet aan die Drie Formuliere van Eenheid', in P. Theron (ed.), Belhar: Geweeg, pp. 66-72, Kraal Uitgewers, Pretoria.

Janse van Rensburg, J., 2012, 'Belhar: Nie as belydenisskrif nie', in P. Theron (ed.), Belhar: Geweeg, pp. 60-65, Kraal Uitgewers, Pretoria.

Jonker, W.D., 1993, 'Die moderne belydenisbeweging in Suid-Afrika en Calvyn', In die Skriflig 27(4), 443-461. https://doi.org/10.4102/ids.v27i4.1472

Lane, T., 2007, A concise history of Christian thought, Clark, London.

Maag, K., 2018, 'Impact amid absence: The synod of Dordt and the French Huguenots', In die Skriflig 52(2), a2340. https://doi.org/10.4102/ids.v52i2.2340

Noordzij, H., 1997, Gereformeerd of protestants: De strijd tussen remonstranted en contra-remonstranten, Uitgeverij Woord en Wereld, Giessendam.

Pelikan, J., 2003, Credo: Historical and theological guide to creeds and confessions of faith in the Christian tradition, Yale University Press, New Haven, CT.

Peterson, R.A. \& Williams, M.D., 2004, Why I am not an Arminian, InterVarsity, Downers Grove, IL.

Sinnema, D., 2011, 'The Canons of Dordt: From judgment on Aminianism to confessional standard', in A. Goudriaan \& F. van Lieburg (eds.), Revisiting the Synod of Dordt: 1618-1619, pp. 313-333, Brill, Leiden.

Sinnema, D., 2017, 'Remembering the Synod of Dordt', Christian Courier March 6, 2017 editorial, viewed 11 April 2018, from http://www.christiancourier.ca/ columns-op-ed/entry/remembering-the-synod-of-dordt

Strauss, P., 2012, 'Hoe geslaag is die kernwaarhede?', in P. Theron (ed.), Belhar: Geweeg, pp. 73-78, Kraal Uitgewers, Pretoria.

Tussenkerklike Raad, Acta 30-31 August 2005, Unpublished.

Tussenkerklike Raad, Acta 25-26 April 2006, Unpublished.

Tussenkerklike Raad, Acta 10-11 April 2007, Unpublished.

Van 't Spijker, W., 1987a, 'De Synode en de Remonstranten', in W. van 't Spijker, C. de Bruin, H. Florijn, A. Moerkerken \& H. Natzijl (eds.), De Synode van Dordrecht in 1618 en 1619, pp. 95-120, Den Hertog, Houten.

Van 't Spijker, W., 1987b, 'Voorgeschiedenis', in W. van 't Spijker, C. de Bruin, H. Florijn, A. Moerkerken \& H. Natzijl (eds.), De Synode van Dordrecht in 1618 en 1619, pp. 11-56, Den Hertog, Houten.

Van Wyk, J.H., 1993, 'Temas uit die kerkgeskiedenis', In die Skriflig 27(2), 281-288. https://doi.org/10.4102/ids.v27i2.1460

Van Wyk, J.H., 1995, 'Die relevansie van die Gereformeerde teologie vir vandag', In die Skriflig 29(1-2), 241-268. https://doi.org/10.4102/ids.v29i1/2.1541

Verboom, W., 2005, De belijdenis van een gebroken kerk: De Dordtse Leerregels, voorgeschiedenis en theologie, Uitgeverij Boekencentrum, Zoetermeer.

Walls, J.L. \& Dongell, J.R., 2004, Why I am not a Calvinist, InterVarsity, Downers Grove, IL. 